\title{
ANALISIS PENGARUH PEMAKAIAN ALAT BANTU ANGKUT TERHADAP SEGMENT TUBUH PEKERJA
}

\author{
Gunawan Madyono Putro \\ Program Studi Teknik Industri Jurusan Teknik Industri Fakultas Teknik Industri UPN "Veteran" \\ Yogyakarta Jl Babarsari 2 Tambak Bayan Yogyakarta 55281 \\ e-mail: bagus2007@ymail.com
}

\begin{abstract}
Abstraksi
Pekerjaan seperti mengangkat dan memindahkan barang seperti beras, pupuk, semen yang dilakukan di bagian pergudangan perlu menggunakan alat bantú. Alat bantú yang tepat dapat mengurangi konsumsi energi yang besar dan beban yang diterima oleh segment tubuh pekerja menjadi lebih ringan sehingga hasil pekerjaan akan lebih optimal. Tetapi sebaliknya dengan diabaikannya alat bantú dapat menyebabkan beban segment tubuh yang diterima pekerja lebih berat sehingga timbul keluhan-keluhan dan dalam jangka yang relatif panjang akan berakibat cidera bahkan cacat tubuh permanen seperti, pembungkukan badan.

Pemakaian alat bantu truk tangan beroda dua yang ergonomis dapat mengurangi konsumsi energi yang dibutuhkan dan untuk mengurangi keluhan segmen tubuh akibat beban fisik yang ditimbulkan dari aktivitas pekerja angkut.

Dari hasil analisis data penelitian diketahui bahwa konsumsi energi yang dikeluarkan sebelum memakai alat bantu sebesar $10.288 \mathrm{kkal} /$ menit dan sesudah memakai alat bantu sebesar 1.7505 kkal/menit. Sedangkan keluhan segmen tubuh berdasarkan nordic body map bagian tubuh lengan bawah kiri mencapai $85.7 \%$, bahu dan punggung sebesar $57.1 \%$. sehingga dapat disimpulkan bahwa pemakaian alat bantu berupa truk tangan beroda dua dapat membantu pekerja dalam pengangkutan barang.
\end{abstract}

Kata kunci : konsumsi energi, segment tubuh, Aktivitas pekerja Angkut

\subsection{PENDAHULUAN}

\section{Pemindahan barang seperti} beras, pupuk, semen, kain yang dilakukan di gudang-gudang saat ini masih banyak yang dilakukan tanpa menggunakan alat bantu. Suatu pekerjaan yang dilakukan dengan cara yang kurang ergonomis akan mengakibatkan banyak keluhan dan pekerjaan yang dihasilkan kurang optimal.

Keluhan rasa capek dan rasa linulinu yang sering dirasakan oleh para pekerja angkut khususnya pada gudang beras adalah tubuh bagian punggung, pinggang, bahu dan kepala. Hal ini apabila dibiarkan dalam jangka waktu yang lama akan berakibat pada cidera dan cacat tubuh seperti pembungkukan badan lebih dini.

Berdasarkan permasalahan tersebut maka perlu penelitian terhadap alat bantu yang akan digunakan, sehingga keluhan pekerja dapat teratasi dan hasil pekerjaan lebih optimal. Penelitian ini dilakukan pada aktivitas pekerja angkut di salah satu gudang beras milik perorangan yang ada di wilayah Berbah Yogyakarta.

\subsection{Tujuan penelitian \\ Tujuan penelitian ini adalah mengetahui tingkat pengaruh pemakaian alat bantu angkut terhadap prosentase penurunan keluhan segment tubuh yang diterima oleh para pekerja.}




\section{LANDASAN TEORI}

\subsection{Ergonomi}

Menurut Sutalaksana (1979), ergonomi dapat didefinisikan sebagai ilmu yang mempelajari sifat, kemampuan dan keterbatasan manusia untuk merancang suatu sistem kerja sehingga orang dapat hidup dan bekerja pada sistem itu dengan baik, yaitu mencapai tujuan yang diinginkan melalui pekerjaan itu dengan efektif, aman dan nyaman. Dari definisi tersebut jelas bahwa fokus ilmu ergonomi adalah manusia itu sendiri dalam arti bahwa dengan sudut pandang ergonomi sedapat mungkin sistem kerja yang disesuaikan dengan sifat, kemampuan dan keterbatasan manusia, bukan sebaliknya.

Peran ergonomi secara praktis dapat dibedakan menjadi tiga kelompok yaitu:

1. Peran ergonomi dalam desain produk.

2. Peran ergonomi dalam upaya meningkatkan keselamatan dan higienis kerja.

3. Peran ergonomi dalam upaya meningkatkan produktivitas kerja.

Tujuan dari penerapan ergonomi adalah:

a. Meningkatkan kesejahteraan fisik dan mental melalui upaya pencegahan cedera dan penyakit akibat kerja, menurunkan beban kerja fisik dan mental, mengupayakan promosi dan kepuasan kerja.

b. Meningkatkan kesejahteraan sosial melalui peningkatan kualitas kontak sosial, mengelola dan mengkoordinir kerja secara tepat guna dan meningkatkan jaminan sosial baik selama kurun waktu usia produktif maupun setelah tidak produktif.

c. Menciptakan keseimbangan rasional antara berbagai aspek yaitu aspek teknis, ekonomis, antropologis dan budaya dari setiap sistem kerja yang dilakukan sehingga tercipta kualitas kerja dan kualitas hidup yang tinggi.

\subsection{Pengertian Anthropometri}

Istilah anthropometri berasal dari kata anthro yang berarti manusia, dan metri yang berarti ukuran. Anthropometri adalah studi tentang dimensi tubuh manusia (Pulat, 1992). Antropometri merupakan suatu ilmu ergonomi yang berkaitan dengan pengukuran dimensi dan karakteristik tertentu dari aspek-aspek lain dari gerakan tubuh manusia.

\subsection{Data Anthropometri dan Cara Pengukurannya}

Manusia pada umumnya akan berbeda-beda dalam hal bentuk dan dimensi ukuran tubuhnya yang mempengaruhi ukuran tubuh manusia antara lain sebagai berikut: (Wignjosoebroto, 1995)
a. Umur
b. Jenis Kelamin
c. Suku/bangsa
d. Posisi Tubuh

Sikap atau posisi tubuh akan berpengaruh terhadap ukuran tubuh oleh sebab itu, posisi tubuh standart harus ditetapkan survei pengukuran. Dalam kaitannya dengan posisi tubuh dikenal 2 cara pengukuran yaitu:

1. Pengukuran Dimensi Struktur Tubuh (Structural Body Dimension)

Disini tubuh akan diukur dalam poisi standart dan tidak bergerak (tetap tegak sempurna). Istilahnya lain dalam pengukuran dengan cara ini dikenal dengan "static anthropometri"..

2. Pengukuran dimensi fungsional tubuh (functional body dimensions)

Disini pengukuran dilakukan terhadap posisi tubuh pada saat berfungsi melakukan gerakangerakan tertentu yang kaitannya 
dengan kegiatan yang harus diselesaikan.

\subsection{Proses Terjadi Kelelahan}

Banyak definisi yang diberikan kepada kelelahan dini tetapi secara garis besarnya dapat dikatakan bahwa kelelahan ini merupakan suatu pola yang timbul pada suatu keadaan yang secara umum terjadi pada setiap individu, yang telah tidak sanggup lagi untuk melakukan aktivitasnya. Pada dasarnya pola ini ditimbulkan oleh dua hal yaitu akibat kelelahan fisiologis (fisik atau kimia) dan akibat kelelahan psikologis (mental atau fungsionil), hal ini bisa bersifat obyektif (akibat perubahan performance) dan bisa bersifat subyektif(akibat perubahan dalam perasaan dan kesadaran) yang dimaksud dengan kelelahan fisiologis adalah kelelahan yang timbul karena adanya perubahan-perubahan fisiologis dalam tubuh. Dari segi fisiologis, tubuh manusia dapat dianggap sebagai mesin yang mengkonsumsi bahan bakar, dan memberikan output berupa tenagatenaga yang berguna untuk melaksanakan aktivitas sehari-hari.

\subsection{Pengukuran Konsumsi Energi}

Energi kerja yang dikonsumsikan pada saat seseorang melaksanakan kegiatan merupakan faktor yang kurang begitu diperhatikan, karena dianggap tidak penting jika dikaitkan dengan performa yang ditunjukkan. Meskipun energi yang dikeluarkan dalam jumlah besar untuk periode lama akan menimbulkan kelelahan fisik, tetapi bahaya yang lebih besar justru jika kelelahan menimpa pada mental manusia.

Tujuan pokok dari perancangan kerja adalah dapat mengheamat energi yang dikonsumsi untuk menyelesaikan suatu kegiatan. Aplikasi prinsip yang dikonsumsi untuk menyelesaikan suatu kegiatan. Aplikasi prinsip energi dalam tahap perncangan dan pengembangan system kerja secara umum dapat meminimlkan konsumsi energi dan meningkatkan efisiensi output kerja.

Secara garis besar, kegiatankegiatan masnuia dapat digolongkan menjadi kerja fisik (otot) dan ker ja mental (otak). Pemisahan ini tidak dapat dilakukan secara sempurna karena keduanya berhubungan erat satu sama lain. Apabila dilihat dari energi yang dikeluarkan, kerja mental adalah relatif lebih sedikit mengeluarkan energi dibandingkan kerja fisik.

Kerja fisik akan mengakibatkan perubahan pada fungsi alat-alat tubuh yang dapat dideteksi melalui perubahan:

a. Konsumsi oksigen

b. Denyut jantung

c. Peredaran darah dalam paru-paru

d. Temperatur tubuh

e. Konsentrasi asam laktat dalam darah

f. Komposisi kimia dalam darah dan air seni

g.Tingkat penguapan dan faktor lainnya.

\subsection{Kecepatan Denyut Jantung}

Kecepatan menyatakan hubungan antara energi dengan kecepatan denyut jantung menggunakan kuantitatif yaitu analisi regresi. Adapun persamaannya sebagai berikut;

$\mathrm{Y}=1,80411-0,0229038 \mathrm{X}+$ $4,71711 \cdot 10^{-4} \cdot X^{2}$

Dengan:

Y : energi (kkal/menit)

$\mathrm{X}$ : kecepatan denyut jantung (denyut/menit)

\subsection{Konsumsi Energi}

Setelah besaran kecepatan dapat disetarakan dalam bentuk energi maka konsumsi energi untuk kerja tertentu dapat dituliskan dalam bentuk persamaan sebagai berikut:

$\mathrm{KE}=\mathrm{Et}-\mathrm{Ei}$

Keterangan: 
KE: Konsumsi energi (Kkal/menit)

Et : Pengeluaran energi pada saat waktu kerja tertentu (kkal/menit)

Ei: Pengeluaran energi pada saat istirahat (kkal/menit)

Dengan demikian konsumsi energi pada waktu kerja tertentu merupakan selisih waktu antara pengeluaran energi pada waktu kerja dengan pengeluaran energi pada saat istirahat.

\subsection{QUICK EXPOSURE CHECK} (QEC)

Quick Exposure Check (QEC) merupakan suatu metode untuk penilaian terhadap resiko kerja yang berhubungan dengan gangguan otot di tempat kerja. Metode ini menilai gangguan resiko yang terjadi pada bagian belakang punggung, bahu/lengan, pergelangan tangan dan leher. Quick Exposure Check (QEC) membantu untuk mencegah terjadinya WMSDs seperti gerak repetitive, gaya tekan, postur yang salah dan durasi kerja. Penilaian pada QEC dilakukan pada tubuh statis dan kerja dinamis untuk memperkirakan tingkat resiko dari postur tubuh dengan melibatkan unsure pengulangan gerakan, tenaga/beban dan lama tugas untuk area tubuh yang berbeda (Li dan Buckle,
1999). Posisi kerja sangat mempengaruhi kinerja pada saat bekerja. Posisi kerja yang kurang baik juga dapat mempercepat terjadinya kelelahan bahkan dapat menyebabkan cidera.

Konsep dasar dari metode ini sebenarnya adalah mengetahui seberapa besar Exposure score untuk bagian tubuh tertentu dibandingkan dengan bagian tubuh lainnya. Exposure score dihitung untuk masing-masing bagian tubuh seperti pada punggung, bahu/lengan atas.

\subsection{KUESIONER NORDIC BODY $M A P$}

Metode untuk mengetahui keluhan muskulosketetal yang merupakan indikasi keluhan fisik adalah dengan meggunkan skala Nordic body map. Melalui Nordic body map dapat diketahui bagian-bagian otot yang mengaami keluhan. Untuk menekan sebisa mungkin terjadi pada saat pengukuran, maka sebaiknya pengukuran dilakukan sebelum dan sesudah melakukan aktivitas kerja (Tarwaka, 2004). Adapun gambar nordic body map dapat dilihat pada Gambar 2.1 :

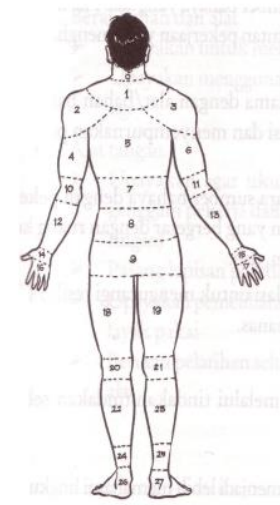

Gambar 2.1 Nordic Body Map

(Sumber: Corlett, 1992)
Keterangan:

0 . Leher bagian atas

1. Leher bagian bawah

Bahu kiri

Bahu kanan

Lengan atas kiri

Punggung

Lengan atas kanan

Pinggang

Pinggul

Pantat

Siku kiri

Siku kanan

Lengan bawah kiri

13. Lengan bawah kanan

14. Pergelangan tangan kiri
15. Pergelangan tangan kanan

16. Tangan kiri

17. Tangan kanan

18. Paha kiri

19. Paha kanan

20. Lutut kiri

21. Lutut kanan

22. Betis kiri

23. Betis kanan

24. Pergelangan kaki kiri

25. Pergelangan kaki kanan

26. Kaki kiri

27. Kaki kanan

15. Pergelangan tangan kanan

\section{PENGUMPULAN DAN PENGOLAHAN DATA}




\subsection{Pengumpulan data}

Data - data yang dibutuhkan dalam penelitian ini diambil seperti pada Gambar 1 dan Gambar 2.

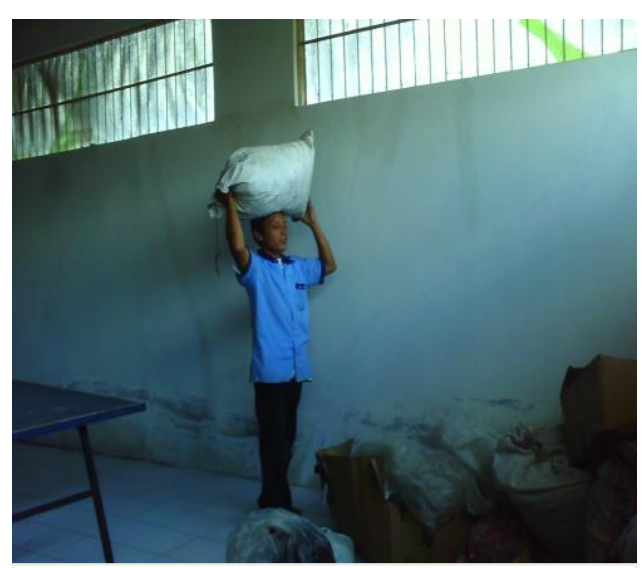

Gambar 1.

Posisi kuli angkut mengangkat benda kerja di Kepala

Gambar 1. Menunjukkan cara pengangkutan beras oleh kuli angkut sebelum memakai alat bantu . Cara pengangkutan seperti ini banyak melibatkan segmen tubuh seperti pungggung, bahu ,pergelangan tangan ,leher dan kepala.

Gambar2. Menunjukkan alat bantu roda dua yang diteliti, yaitu meliputi panjang pegangan $115 \mathrm{~cm}$, lebar $38.5 \mathrm{~cm}$, panjang tempat beban $28 \mathrm{~cm}$, lebar $38.5 \mathrm{~cm}$, panjang

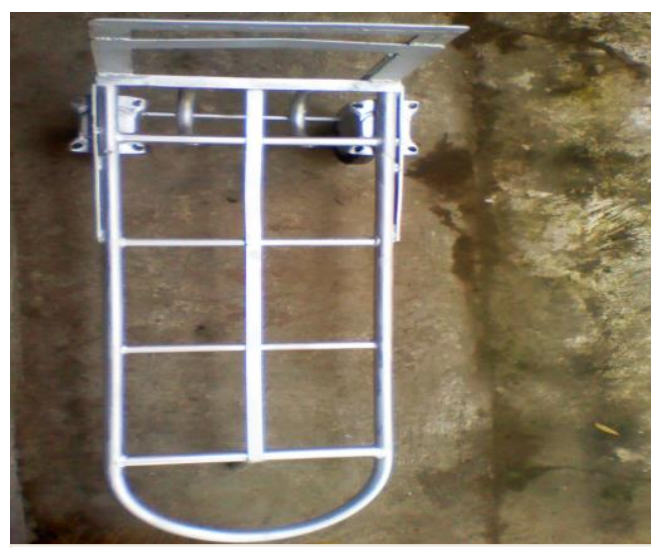

Gambar 2.

Alat Truk Tangan Beroda Dua Tampak Atas

kaki $20 \mathrm{~cm}$ serta ukuran jari-jari roda $16 \mathrm{~cm}, \mathrm{r}$ $=8 \mathrm{~cm}$.

\subsection{Pengolahan Data}

Metode pengolahan data yang dilakukan melalui tahapan-tahapan sebagai berikut:

1. Menghitung data antropometri tiap-tiap pekerja.

Adapun data anthropometri dari 15 pekerja yang digunakan untuk sampel penelitian dapat dilihat pada Tabel 1.

Tabel 1. Data Antropometri dari 15 pekerja dengan satuan centimeter $(\mathrm{cm})$

\begin{tabular}{|c|c|c|c|c|c|}
\hline $\begin{array}{c}\text { Nama } \\
\text { Pekerja }\end{array}$ & $\begin{array}{c}\text { Tinggi Badan } \\
\text { Tegak (Tbt) }\end{array}$ & $\begin{array}{c}\text { Jangkuan } \\
\text { Tangan Atas } \\
\text { (JTA) }\end{array}$ & $\begin{array}{c}\text { Jangkuan Tangan } \\
\text { Depan (JTD) }\end{array}$ & $\begin{array}{c}\text { Rentangan } \\
\text { Tangan (RT) }\end{array}$ & $\begin{array}{c}\text { Lebar } \\
\text { Tangan (LT) }\end{array}$ \\
\hline A & 167 & 223 & 83 & 174 & 10 \\
\hline B & 175 & 208 & 81 & 168 & 10 \\
\hline C & 172 & 208 & 84 & 173 & 9 \\
\hline D & 155 & 229 & 81 & 171 & 9.5 \\
\hline E & 168 & 195 & 86 & 177 & 9.5 \\
\hline F & 164 & 212 & 79 & 154 & 8.6 \\
\hline G & 167 & 208 & 77 & 176 & 9.5 \\
\hline H & 160 & 197 & 73 & 178 & 9.4 \\
\hline I & 181 & 203 & 80 & 173 & 7.5 \\
\hline J & 172 & 235 & 76 & 165 & 7.5 \\
\hline
\end{tabular}




\begin{tabular}{|c|c|c|c|c|c|}
\hline $\begin{array}{c}\text { Nama } \\
\text { Pekerja }\end{array}$ & $\begin{array}{c}\text { Tinggi Badan } \\
\text { Tegak (Tbt) }\end{array}$ & $\begin{array}{c}\text { Jangkuan } \\
\text { Tangan Atas } \\
\text { (JTA) }\end{array}$ & $\begin{array}{c}\text { Jangkuan Tangan } \\
\text { Depan (JTD) }\end{array}$ & $\begin{array}{c}\text { Rentangan } \\
\text { Tangan (RT) }\end{array}$ & $\begin{array}{c}\text { Lebar } \\
\text { Tangan (LT) }\end{array}$ \\
\hline K & 152 & 224 & 77 & 176 & 10 \\
\hline L & 158 & 194 & 89 & 171 & 9.5 \\
\hline M & 172 & 202 & 80 & 154 & 10 \\
\hline N & 156 & 220 & 77 & 176 & 8.5 \\
\hline O & 176 & 223 & 84 & 162 & 7.5 \\
\hline
\end{tabular}

2. Menghitung jumlah konsumsi energi sebelum dan sesudah memakai alat bantu.

Tabel 2. Hasil Perhitungan Konsumsi Energi Sebelum dan Sesudah memakai Alat Bantu

\begin{tabular}{|c|c|c|c|c|c|c|c|}
\hline \multirow{2}{*}{ No } & \multirow{2}{*}{ Pekerja } & \multicolumn{3}{|c|}{ Sebelum } & \multicolumn{3}{c|}{ Sesudah } \\
\cline { 3 - 7 } & & Y1 & Y2 & KE & Y1 & Y2 & KE \\
\hline 1 & A & 2,388 & 11,135 & 8,748 & 2.3084 & 3.5023 & 1.1939 \\
\hline 2 & B & 2,470 & 11,821 & 9,351 & 2.2705 & 4.0210 & 1.7505 \\
\hline 3 & C & 2,428 & 11,406 & 8,978 & 2.3084 & 3.0979 & 0.7895 \\
\hline 4 & D & 2,470 & 12,243 & 9,773 & 2.3084 & 3.6897 & 1.3813 \\
\hline 5 & E & 2,232 & 11,960 & 9,728 & 2.2705 & 3.5638 & 1.2933 \\
\hline 6 & F & 2,388 & 12,676 & 10,288 & 2.3084 & 3.8856 & 1.5772 \\
\hline 7 & G & 2,428 & 11,271 & 8,843 & 2.3084 & 3.3233 & 1.0149 \\
\hline 8. & H & 2,388 & 11,135 & 8,748 & 2.3084 & 3.5023 & 1.1939 \\
\hline 9. & I & 2,470 & 11,821 & 9,351 & 2.2705 & 4.0210 & 1.7505 \\
\hline 10. & J & 2,428 & 11,406 & 8,978 & 2.3084 & 3.0979 & 0.7895 \\
\hline 11. & K & 2,470 & 12,243 & 9,773 & 2.3084 & 3.6897 & 1.3813 \\
\hline 12. & L & 2,232 & 11,960 & 9,728 & 2.2705 & 3.5638 & 1.2933 \\
\hline 13. & M & 2,388 & 12,676 & 10,288 & 2.3084 & 3.8856 & 1.5772 \\
\hline 14. & N & 2,428 & 11,271 & 8,843 & 2.3084 & 3.3233 & 1.0149 \\
\hline 15. & O & 2,388 & 11,135 & 8,748 & 2.3084 & 3.5023 & 1.1939 \\
\hline
\end{tabular}

Keterangan :

$\mathrm{Y} 1: \operatorname{Er}(\mathrm{Kkal} / \mathrm{menit})$

Y2 : Et (Kkal/menit)

$\mathrm{KE}:$ Et-Er (Kkal/menit)

3. Menghitung Persentase Nordic

Body Map

Dilihat dari hasil pengisian kuesioner Nordic Body Map
Maka dapat dihitung persentase tingkat keluhan pada setiap pekerja. Hasil perhitungan persentase tingkat keluhan dapet dilihat pada Tabel 3 .

Tabel 3. Hasil Perhitungan Persentase Tingkat Keluhan (\%) Sebelum dan Sesudah memakai Alat Bantu 


\begin{tabular}{|c|c|c|c|c|c|c|c|c|c|}
\hline \multirow{2}{*}{ Notasi } & \multirow{2}{*}{ Segmen Tubuh } & \multicolumn{4}{|c|}{ sebelum } & \multicolumn{4}{|c|}{ Sesudah } \\
\hline & & 1 & 2 & 3 & 4 & 1 & 2 & 3 & 4 \\
\hline 0 & Leher bagian atas & 28,6 & 28,6 & 28,6 & 14,3 & 57.13 & $\begin{array}{c}42.85 \\
7\end{array}$ & - & - \\
\hline 1 & Leher bagian bawah & 28,6 & 14,3 & 28,6 & 28,6 & 71.49 & $\begin{array}{c}28.57 \\
1\end{array}$ & - & - \\
\hline 2 & Bahu kiri & 14,3 & 14,3 & 14,3 & 57,1 & 42.87 & $\begin{array}{c}42.85 \\
7\end{array}$ & $\begin{array}{c}14.28 \\
6\end{array}$ & - \\
\hline 3 & Bahu kanan & 14,3 & 14,3 & 42,9 & 28,6 & 57.13 & $\begin{array}{c}42.85 \\
7\end{array}$ & - & - \\
\hline 4 & Lengan atas kiri & - & 14,3 & 42,9 & 42,9 & 42.87 & $\begin{array}{c}57.14 \\
3\end{array}$ & - & - \\
\hline 5 & Punggung & 14,3 & 14,3 & 14,3 & 57,1 & 85.7 & 14.3 & - & - \\
\hline 6 & Lengan atas kanan & 28,6 & 42,9 & 28,6 & - & 71.4 & 28.6 & - & - \\
\hline 7 & Pinggang & - & 28,6 & 28,6 & 42,9 & 71.4 & 28.6 & - & - \\
\hline 8 & Pinggul & 42,9 & 42,9 & 14,3 & - & 57.1 & 42.9 & - & - \\
\hline 9 & Pantat & 57,1 & 42,9 & - & - & 57,1 & 42,9 & - & - \\
\hline 10 & Siku kiri & 42,9 & 14,3 & 42,9 & - & 85.7 & 14.3 & - & - \\
\hline 11 & Siku kanan & 42,9 & - & 57,1 & - & 100 & - & - & - \\
\hline 12 & Lengan bawah kiri & - & 14,3 & 85,7 & - & 14.3 & 85.7 & - & - \\
\hline 13 & Lengan bawah kanan & 28,6 & 42,9 & 28,6 & - & 57.1 & 42.9 & - & - \\
\hline 14 & Pergelangan tangan kiri & 14,3 & 28,6 & 57,1 & - & - & 14.3 & 85.7 & - \\
\hline 15 & Pergelangan tangan kanan & 42,9 & 28,6 & 28,6 & - & - & 71.4 & 28.6 & - \\
\hline 16 & Rangapkinion. & - & 57,1 & 28,6 & 14,3 & - & 85.7 & 14.3 & - \\
\hline 17 & Kangan kanan & 14,3 & 14,3 & 42,9 & 28,6 & 14.3 & 57.1 & 28.6 & - \\
\hline $\mathrm{K}_{18}$ & Paha kiri & 14,3 & 28,6 & 28,6 & 14,3 & 42.9 & 57.1 & - & - \\
\hline O 19 & Paha kanan & 14,3 & 42,9 & 42,9 & - & 57.1 & 42.9 & - & - \\
\hline $1_{20}$ & Lutut kiri & 14,3 & 28,6 & 57,1 & - & 85.7 & 14.3 & - & - \\
\hline $\mathrm{O}_{21}$ & Lutut kanan & 14,3 & 14,3 & 71,4 & - & 85.7 & 14.3 & - & - \\
\hline $\mathrm{m}_{22}$ & Betis kiri & 14,3 & 28,6 & 57,1 & - & 14,3 & 28,6 & 57,1 & - \\
\hline 123 & Betis kanan & 14,3 & 42,9 & 42,9 & - & 14,3 & 42,9 & 42,9 & - \\
\hline 24 & Pergelangan kaki kiri & 57,1 & 42,9 & - & - & 57,1 & 42,9 & - & - \\
\hline$=25$ & Pergelangan kaki kanan & 57,1 & 42,9 & - & - & 57,1 & 42,9 & - & - \\
\hline 26 & Kaki kiri & 14,3 & 71,4 & 14,3 & - & 28.6 & 71.4 & - & - \\
\hline$t_{27}$ & Kaki kanan & 14,3 & 71,4 & 14,3 & - & 28.6 & 71.4 & - & - \\
\hline
\end{tabular}

dak sakit

Kolom 3 = sakit

Kolom 2 = agak sakit $\quad$ Kolom $4=$ sakit sekali

\section{Menghitung Exsposure Score}

Tabel 4. Hasil perhitungan Exposure score Sebelum dan Sesudah memakai alat bantu 


\begin{tabular}{|c|c|c|c|c|c|c|c|c|}
\hline \multirow{2}{*}{$\begin{array}{l}\text { Segmen } \\
\text { Tubuh } \\
\text { Pekerja }\end{array}$} & \multicolumn{9}{|c|}{ Sebelum } & \multicolumn{4}{c|}{ Sesudah } \\
\cline { 2 - 9 } & Punggung & $\begin{array}{c}\text { Bah } \\
\mathrm{u}\end{array}$ & $\begin{array}{l}\text { Pergelangan } \\
\text { Tangan }\end{array}$ & Leher & $\begin{array}{c}\text { Punggu } \\
\text { ng }\end{array}$ & Bahu & $\begin{array}{c}\text { Pergelan } \\
\text { gan } \\
\text { Tangan }\end{array}$ & Leher \\
\hline A & 14 & 12 & 12 & 12 & 6 & 12 & 10 & 8 \\
\hline B & 12 & 14 & 10 & 15 & 10 & 12 & 10 & 8 \\
\hline C & 24 & 20 & 16 & 9 & 12 & 20 & 10 & 9 \\
\hline D & 18 & 8 & 14 & 12 & 16 & 10 & 12 & 8 \\
\hline E & 18 & 10 & 14 & 10 & 16 & 8 & 12 & 10 \\
\hline F & 16 & 18 & 10 & 17 & 12 & 12 & 8 & 10 \\
\hline G & 16 & 16 & 10 & 15 & 10 & 12 & 8 & 10 \\
\hline H & 14 & 12 & 12 & 12 & 6 & 12 & 10 & 8 \\
\hline I & 12 & 14 & 10 & 15 & 10 & 12 & 10 & 8 \\
\hline J & 24 & 20 & 16 & 9 & 12 & 20 & 10 & 9 \\
\hline K & 18 & 8 & 14 & 12 & 16 & 10 & 12 & 8 \\
\hline L & 18 & 10 & 14 & 10 & 16 & 8 & 12 & 10 \\
\hline M & 16 & 18 & 10 & 17 & 12 & 12 & 8 & 10 \\
\hline N & 16 & 16 & 10 & 15 & 10 & 12 & 8 & 10 \\
\hline O & 14 & 12 & 12 & 12 & 6 & 12 & 10 & 8 \\
\hline$\sum X$ & 250 & 208 & 184 & 192 & 174 & 184 & 148 & 136 \\
\hline $\mathrm{N}$ & 15 & 15 & 15 & 15 & 15 & 15 & 15 & 15 \\
\hline
\end{tabular}

5. Menghitung Beban fisik sebelum dan setelah memakai alat bantu. Setelah dilakukan penelitian dengan memakai alat

bantu, maka beban fisik berdasarkan denyut nadi pekerja kuli angkut mengalami penurunan seperti pada Tabel 5.

Tabel 5. Data Denyut Nadi Sesudah memakai alat bantu

\begin{tabular}{|c|c|c|c|}
\hline No. & Nama Pekerja & $\begin{array}{c}\text { Sebelum bekerja Jam 08.00 } \\
\text { (denyut/menit) }\end{array}$ & $\begin{array}{c}\text { Sesudah bekerja Jam } 16.00 \\
\text { (denyut/menit) }\end{array}$ \\
\hline 1. & A & 65 & 89 \\
\hline 2. & B & 64 & 97 \\
\hline 3. & C & 65 & 82 \\
\hline 4. & D & 65 & 92 \\
\hline 5. & E & 64 & 99 \\
\hline 6. & F & 65 & 95 \\
\hline 7. & G & 65 & 86 \\
\hline 8. & H & 65 & 89 \\
\hline 9. & I & 64 & 97 \\
\hline 10. & J & 65 & 82 \\
\hline 11. & K & 65 & 92 \\
\hline 12. & L & 64 & 90 \\
\hline 13. & M & 65 & 95 \\
\hline 14. & N & 65 & 86 \\
\hline 15. & O & 65 & 89 \\
\hline
\end{tabular}

Dilihat dari Tabel 2 dapat diketahui bahwa konsumsi energi pada masingmasing pekerja setelah menggunakan alat bantu berkurang rata -rata $50 \%$.

\subsection{Pembahasan}

Hal ini disebabkan karena pengeluaran 
energi pada waktu bekerja lebih kecil. Sedangkan keluhan segmen tubuh berdasarkan Nordic Body Map berdasarkan Tabel 3 diketahui bahwa beberapa keluhan rasa sakit pada segment tubuh seperti pergelangan tangan, leher, bahu dan punggung menjadi berkurang. Hal ini disebabkan segment-segment tubuh tidak mendapat tekanan ataupun mengangkat langsung dari benda yang diangkut, dan ukuran alat bantu telah sesuai dengan data antropometri tubuh pekerja.

Adapun tabel interpretasi score segment tubuh sebelum dan sesudah pemakaian dapat dilihat pada Tabel 6 .

Tabel 6. Interpretasi Score segmen tubuh sebelum dan sesudah pemakaian alat bantu

\begin{tabular}{|l|c|c|c|c|}
\hline \multirow{2}{*}{ Segmen Tubuh } & \multicolumn{2}{|c|}{ Sebelum } & \multicolumn{2}{c|}{ Sesudah } \\
\cline { 2 - 5 } & $\begin{array}{c}\text { Score rata- } \\
\text { rata }\end{array}$ & $\begin{array}{c}\text { Exsposure } \\
\text { level }\end{array}$ & $\begin{array}{c}\text { Score rata- } \\
\text { rata }\end{array}$ & Exsposure level \\
\hline Punggung & 16,7 & Moderate & 11,6 & Low \\
\hline Bahu & 13,9 & Moderate & 12,3 & Low \\
\hline Pergelangan Tangan & 12,3 & Low & 9,9 & Low \\
\hline Leher & 12,8 & High & 9,07 & Low \\
\hline
\end{tabular}

\section{KESIMPULAN}

Alat angkut yang digunakan untuk pengangkutan beras seperti pada gambar 1, dapat mengurangi konsumsi energi sebesar $82,82 \%$ dibandingkan apabila tidak menggunakan alat bantu . Sedangkan keluhan segmen tubuh berdasarkan nordic body map bagian tubuh seperti punggung berkurang $30 \%$, pergelangan tangan berkurang $28 \%$, leher berkurang $29 \%$ dan bahu 14\% sehingga dapat disimpulkan bahwa alat bantu yang sudah ada layak untuk digunakan.

\section{DAFTAR PUSTAKA}

Brown,R. And Li,G. 2003. The Development of Action Levels for the Quick Exposure Check (QEC) System. In : Contemporary Ergonomics 2003,(ed. P. T. Mc Cabe), London Taylor\&Francis, 41-46.

Li, G. dan Buckle,P. 1999. "Current Teechniques for assessing Physical Exposure to Work-Related
Musculuskeletal Risk, with Emphasis on Posturew-Based Methods", Ergonomics, 42(5): 674-695

Nurmianto, E., 1995. Ergonomi, Konsep Dasar dan Aplikasinya, PT. Guna Darma, Jakarta.

Pulat, BM. 1992. Fundamental of Industrial Ergonomic. Prectise Hall Englewood Cliffs New Jersey.

Suma'mur, P.K. 1989. Ergonomi untuk Produktivitas Kerja. Jakarta : PT. Temprint.

Sutalaksana, I.Z., 1979. Teknik Tata Cara Kerja. Departemen Teknik Industri. Bandung

Sutalaksana, I.Z., 2006. Teknik Tata Cara Kerja. Departemen Teknik Industri. Bandung.

Tarwaka., B., Solichul, H.A., dan Wignjosoebroto, S., 1995, Ergonomi Studi Gerak dan Waktu, Guna Widya, Jakarta 